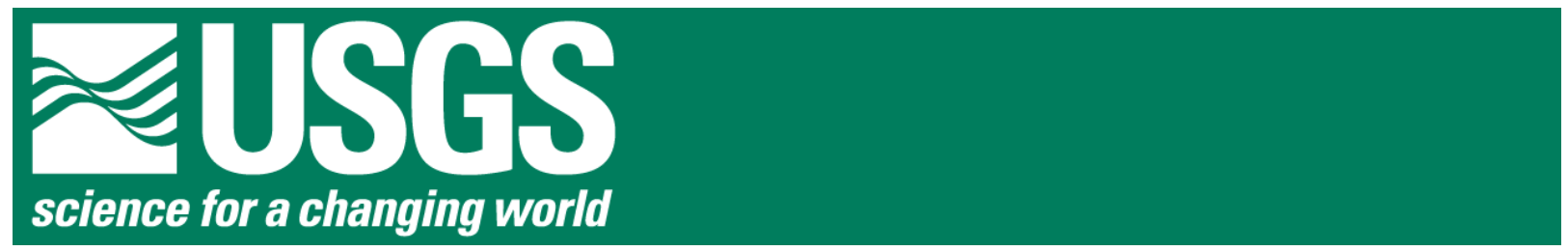

\title{
Vegetation and Substrate Properties of Aeolian Dune Fields in the Colorado River Corridor, Grand Canyon, Arizona
}

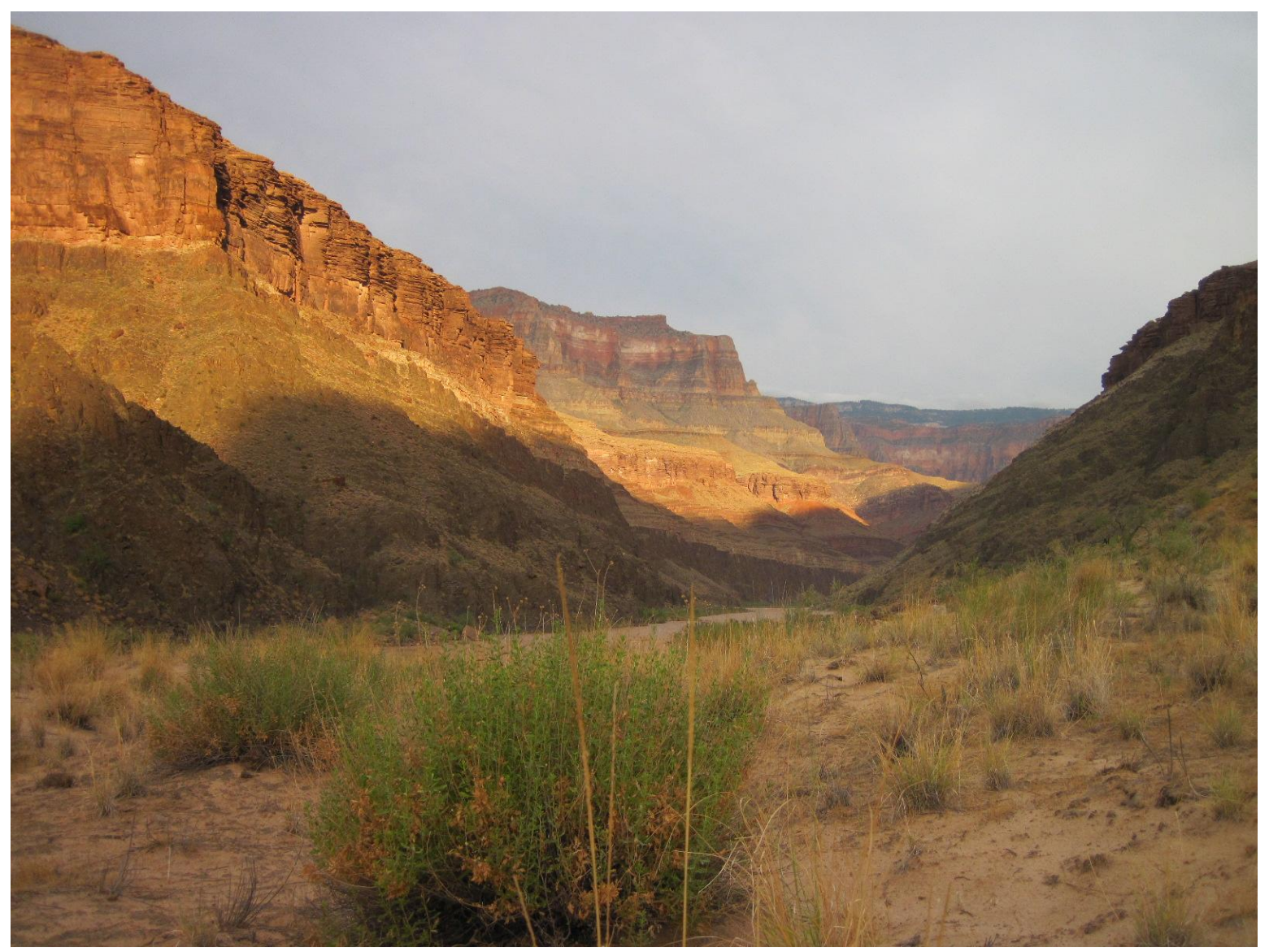

Open-File Report 2011-1195

U.S. Department of the Interior U.S. Geological Survey 
This page intentionally left blank 


\section{Vegetation and Substrate Properties of Aeolian Dune Fields in the Colorado River Corridor, Grand Canyon, Arizona}

By Amy E. Draut

Open-File Report 2011-1195

U.S. Department of the Interior

U.S. Geological Survey 


\section{U.S. Department of the Interior \\ KEN SALAZAR, Secretary}

\section{U.S. Geological Survey \\ Marcia K. McNutt, Director}

U.S. Geological Survey, Reston, Virginia: 2011

For product and ordering information:

World Wide Web: http://www.usgs.gov/pubprod

Telephone: 1-888-ASK-USGS

For more information on the USGS-the Federal source for science about the Earth,

its natural and living resources, natural hazards, and the environment:

World Wide Web: http://www.usgs.gov

Telephone: 1-888-ASK-USGS

Suggested citation:

Draut, A.E., 2011, Vegetation and substrate properties of aeolian dune fields in the Colorado River corridor, Grand Canyon, Arizona: U.S. Geological Survey Open-File Report 2011-1195, 16 p., available at http://pubs.usgs.gov/of/2011/1195/

Any use of trade, product, or firm names is for descriptive purposes only and does not imply endorsement by the U.S. Government.

Although this report is in the public domain, permission must be secured from the individual copyright owners to reproduce any copyrighted material contained within this report. 


\section{Contents}

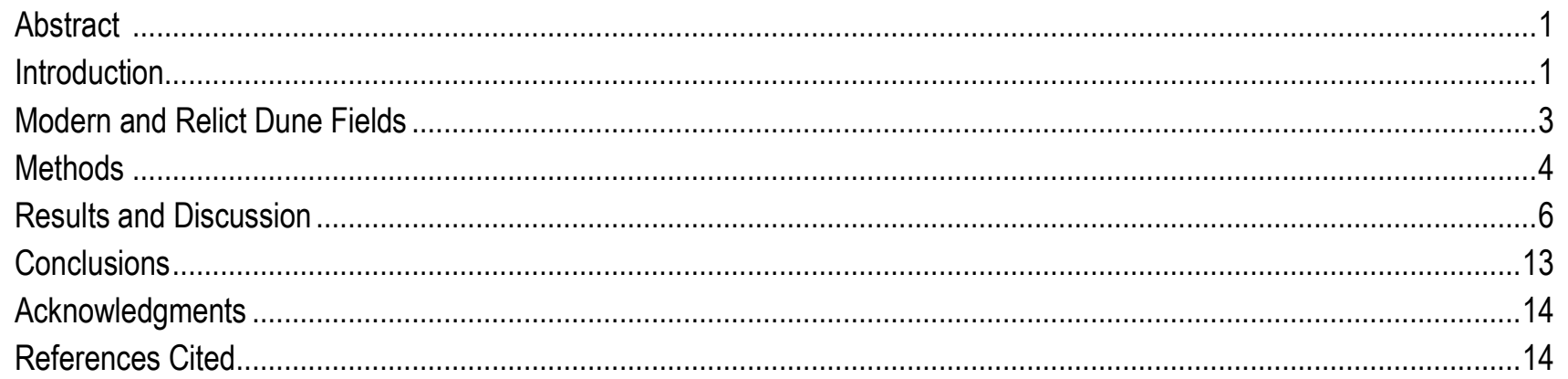

\section{Figures}

1. Location map of study sites in the Colorado River corridor, Grand Canyon, Arizona.................................................2

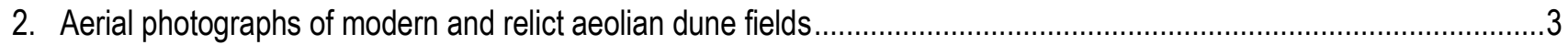

3. Scale diagram of "pod" configuration used to map vegetation and substrate..............................................................5

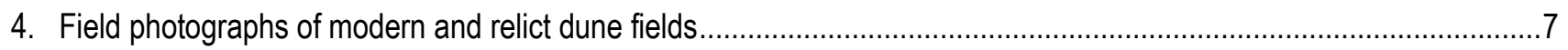

5. Plots of vegetation cover, biologic crust abundance, and gap length in dune fields...................................................8

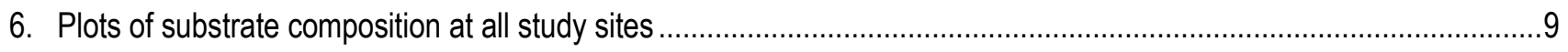

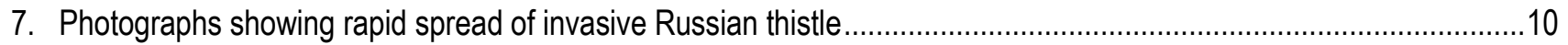

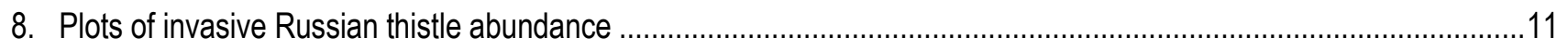

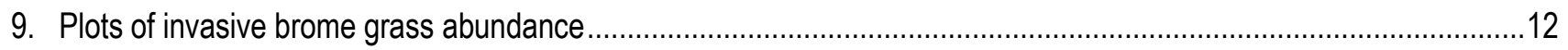

10. Comparison of Grand Canyon with Cataract Canyon vegetation ............................................................................13

Tables Available at http://pubs.usgs.gov/of/2011/1195/of2011-1195_tables/

1. Summary of site locations and findings.

2. Vegetation cover and substrate properties measured at $24.7 \mathrm{~L}$, lower site.

3. Vegetation cover and substrate properties measured at $24.7 \mathrm{~L}$, upper site.

4. Vegetation cover and substrate properties measured at $44.0 \mathrm{~L}$.

5. Vegetation cover and substrate properties measured at $50.1 \mathrm{R}$.

6. Vegetation cover and substrate properties measured at $57.9 \mathrm{R}$, lower site.

7. Vegetation cover and substrate properties measured at $57.9 \mathrm{R}$, upper site.

8. Vegetation cover and substrate properties measured at $60.0 \mathrm{R}$.

9. Vegetation cover and substrate properties measured at $60.1 \mathrm{R}$.

10. Vegetation cover and substrate properties measured at $65.5 \mathrm{~L}$.

11. Vegetation cover and substrate properties measured at $68.0 \mathrm{~L}$.

12. Vegetation cover and substrate properties measured at $68.1 \mathrm{~L}$.

13. Vegetation cover and substrate properties measured at $69.0 \mathrm{R}$.

14. Vegetation cover and substrate properties measured at $69.5 \mathrm{R}$.

15. Vegetation cover and substrate properties measured at $70.0 \mathrm{~L}$, lower site. 
16. Vegetation cover and substrate properties measured at $70.0 \mathrm{~L}$, upper site.

17. Vegetation cover and substrate properties measured at $72.3 \mathrm{~L}$.

18. Vegetation cover and substrate properties measured at $93.3 \mathrm{~L}$.

19. Vegetation cover and substrate properties measured at $109.0 \mathrm{R}$.

20. Vegetation cover and substrate properties measured at $122.5 \mathrm{~L}$.

21. Vegetation cover and substrate properties measured at $123.0 \mathrm{~L}$.

22. Vegetation cover and substrate properties measured at $134.5 \mathrm{~L}$.

23. Vegetation cover and substrate properties measured at $135.0 \mathrm{~L}$.

24. Vegetation cover and substrate properties measured at $171.5 \mathrm{~L}$.

25. Vegetation cover and substrate properties measured at $202.9 \mathrm{R}$.

26. Vegetation cover and substrate properties measured at 207.0 L.

27. Vegetation cover and substrate properties measured at $209.0 \mathrm{~L}$.

28. Vegetation cover and substrate properties measured at 223.0 R. 


\title{
Vegetation and Substrate Properties of Aeolian Dune Fields in the Colorado River Corridor, Grand Canyon, Arizona
}

\author{
By Amy E. Draut ${ }^{1}$
}

\begin{abstract}
This report summarizes vegetation and substrate properties of aeolian landscapes in the Colorado River corridor through Grand Canyon, Arizona, in Grand Canyon National Park. Characterizing these parameters provides a basis from which to assess future changes in this ecosystem, including the spread of nonnative plant species. Differences are apparent between aeolian dune fields that are downwind of where modern controlled flooding deposits new sandbars (modern-fluvial-sourced dune fields) and those that have received little or no new windblown sand since river regulation began in the 1960s (relict-fluvial-sourced dune fields). The most substantial difference between modern- and relict-fluvialsourced aeolian dune fields is the greater abundance of biologic soil crust in relict dune fields. These findings can be used with similar investigations in other geomorphic settings in Grand Canyon and elsewhere in the Colorado River corridor to evaluate the health of the Colorado River ecosystem over time.
\end{abstract}

\section{Introduction}

The Colorado River corridor through Grand Canyon National Park, Arizona, hosts a complex riparian and dryland ecosystem that spans more than two hundred miles along the river and more than two thousand feet of elevation change at river level alone between Lees Ferry and Diamond Creek (fig. 1). Many scientific studies focus on assessing the effects of river regulation at Glen Canyon Dam on the river-corridor ecosystem downstream (for example, Gloss and others, 2005). As a supplement to studies of windblown sand transport in the river corridor (Draut and Rubin, 2008; Draut and others, 2009a,b, 2010a), this report presents vegetation and substrate measurements made in landscapes above the current high water line $\left(1,200 \mathrm{~m}^{3} / \mathrm{s}\right)$ in the Colorado River corridor that are characterized by aeolian (windblown) sedimentary deposits and processes. The results illustrate some ecological differences between aeolian dune fields that receive modern sand supply and others that do not, and also provide a basis from which to evaluate future changes in this ecosystem, including the possible further spread of nonnative plant species.

The Colorado River flow and sediment supply in Grand Canyon have changed substantially since Glen Canyon Dam was completed in 1963 (Topping and others, 2000, 2003; Rubin and others, 2002). The dam has reduced the fluvial sediment supply to upper Marble Canyon by about 95 percent

\footnotetext{
${ }^{1}$ U.S. Geological Survey Pacific Coastal and Marine Science Center, Santa Cruz, CA 95060.
} 
(Topping and others, 2000). Without natural floods, the river does not deposit sediment at elevations that received it regularly before dam closure. Owing to the loss of sediment supply and reduction in the magnitude and frequency of floods, the size and number of fluvial sandbars has decreased in the river corridor since the 1960s (Beus and others, 1985; Schmidt and Graf, 1990; Kearsley and others, 1994; Gloss and others, 2005; Hazel and others, 2010). In an effort to rebuild sandbars, controlled floods were released from Glen Canyon Dam in 1996, 2004, and 2008 (Webb and others 1999; Topping and others, 2010; Melis, 2011) that mobilized sediment delivered by natural tributary floods. Although sandbar response to controlled flooding is a complex function of the amount and grain size of tributary sand in the main channel, and although the controlled-flood magnitudes have been substantially less than the predam annual flood peak (Topping and others, 2003), those three floods have shown that a 60 -hour, $1,160 \mathrm{~m}^{3} / \mathrm{s}$ controlled flood can increase sandbar area and volume in Marble and Grand Canyons, at least temporarily (Hazel and others, 2010).

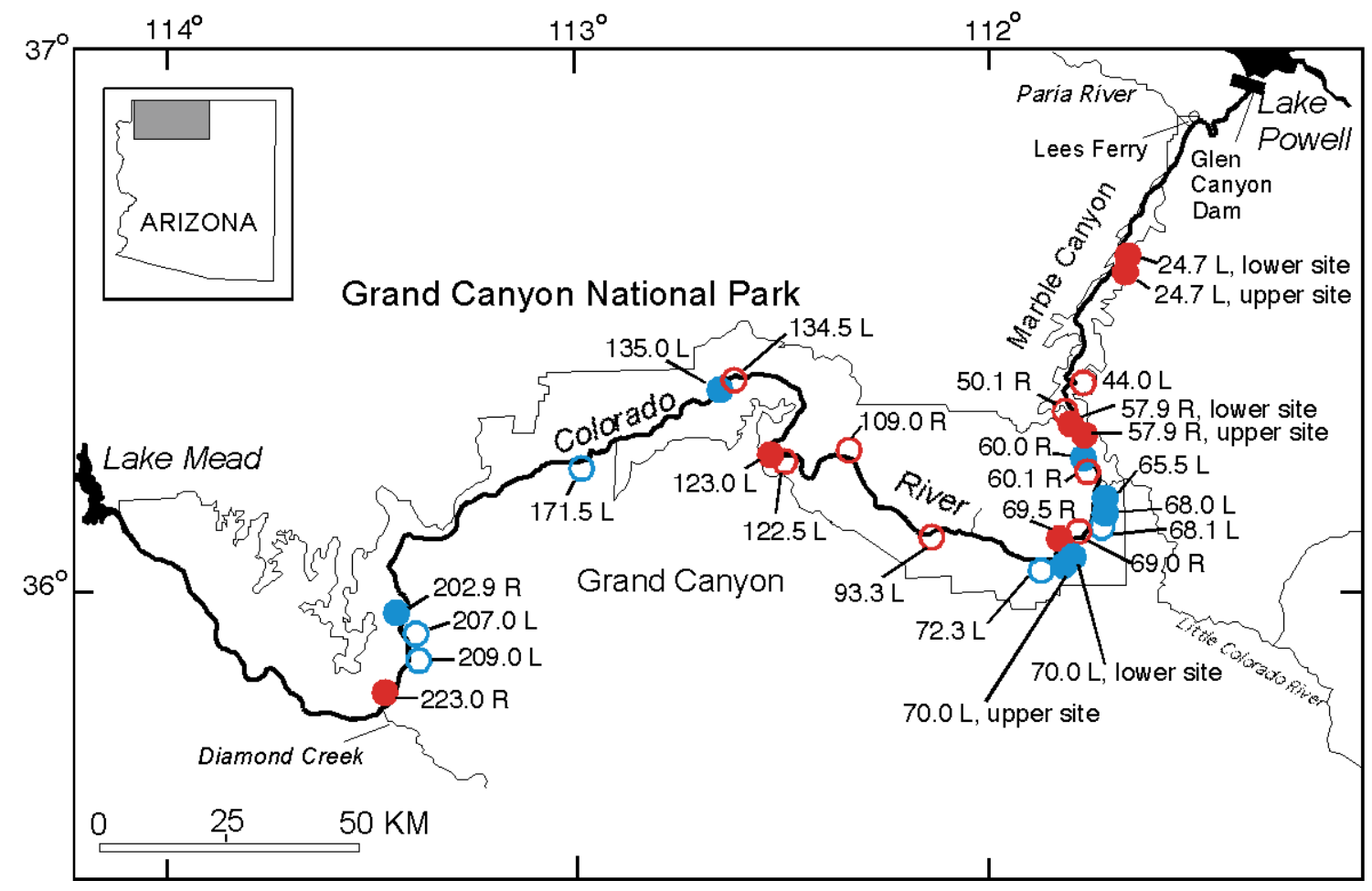

Figure 1. Map showing study area in Grand Canyon National Park, Arizona. Study sites are labeled by river mile and bank (L, left, $R$, right bank when viewed facing downstream). Red circles are modern-fluvial-sourced (MFS) dune fields and blue circles are relict-fluvial-sourced (RFS) dune fields. Filled red and blue circles are sites where weather stations operated. Vegetation and substrate were measured at all sites (filled and open circles).

Plant communities within the river corridor include true riparian vegetation, composed of species with roots that reach river water, and many other species that live at higher elevations where precipitation is the only source of water. The riparian vegetation community, dominated by willow (Salix spp.), seepwillow (Baccharis spp.), tamarisk (Tamarix ramosissima and hybrids thereof), and arrowweed (Pluchea sericea), occupies lower elevations in the modern era of flow regulation than it did before Glen Canyon Dam operations reduced the magnitude and frequency of floods (Turner and Karpiscak, 1980; Huisinga and others, 2006). In many places, riparian vegetation now fills areas that 
were formerly open sandbars (Turner and Karpiscak, 1980). The predam high water line is evident in many areas of the canyon, marked by shrubs and trees such as western honey mesquite (Prosopis glandulosa), catclaw acacia (Acacia gregii), netleaf hackberry (Celtis laevigata), and western redbud (Cercis orbiculata). The vegetation communities measured in this study were above the modern, controlled-flood high water line and, therefore, were composed primarily of plants that do not depend on river water, although occasional riparian plants can occur in the lowest-elevation areas of aeolian dune fields.

\section{Modern and Relict Dune Fields}

In dryland river corridors, subaerially exposed fluvial sediment can be reworked by wind to form aeolian dunes. In Grand Canyon, aeolian dunes can form directly inland from some of the modern sandbars deposited by controlled floods - after the floods recede, in places where the dominant wind direction is oriented inland from the river, wind brings sand above the high-water line (Draut and others, 2010b). Other aeolian landscapes in the Colorado River corridor through Grand Canyon formed decades or centuries ago as the wind reworked sediment left by large, predam floods (Hereford, 1996; Draut and others, 2008). The locations of aeolian dune fields in Grand Canyon relative to fluvial sandbars and wind patterns indicate whether modern, postdam sediment supply is available to the dune fields. Aeolian landscapes there can be grouped into two types (Draut and Rubin, 2008): (1) modern-fluvial-sourced (MFS) dune fields, which are downwind from the Colorado River no matter what its flow stage; and (2) relict-fluvial-sourced (RFS) dune fields, which are downwind of places where the river deposited sand only during large, predam floods. Figure 2 shows examples of each type of dune field.
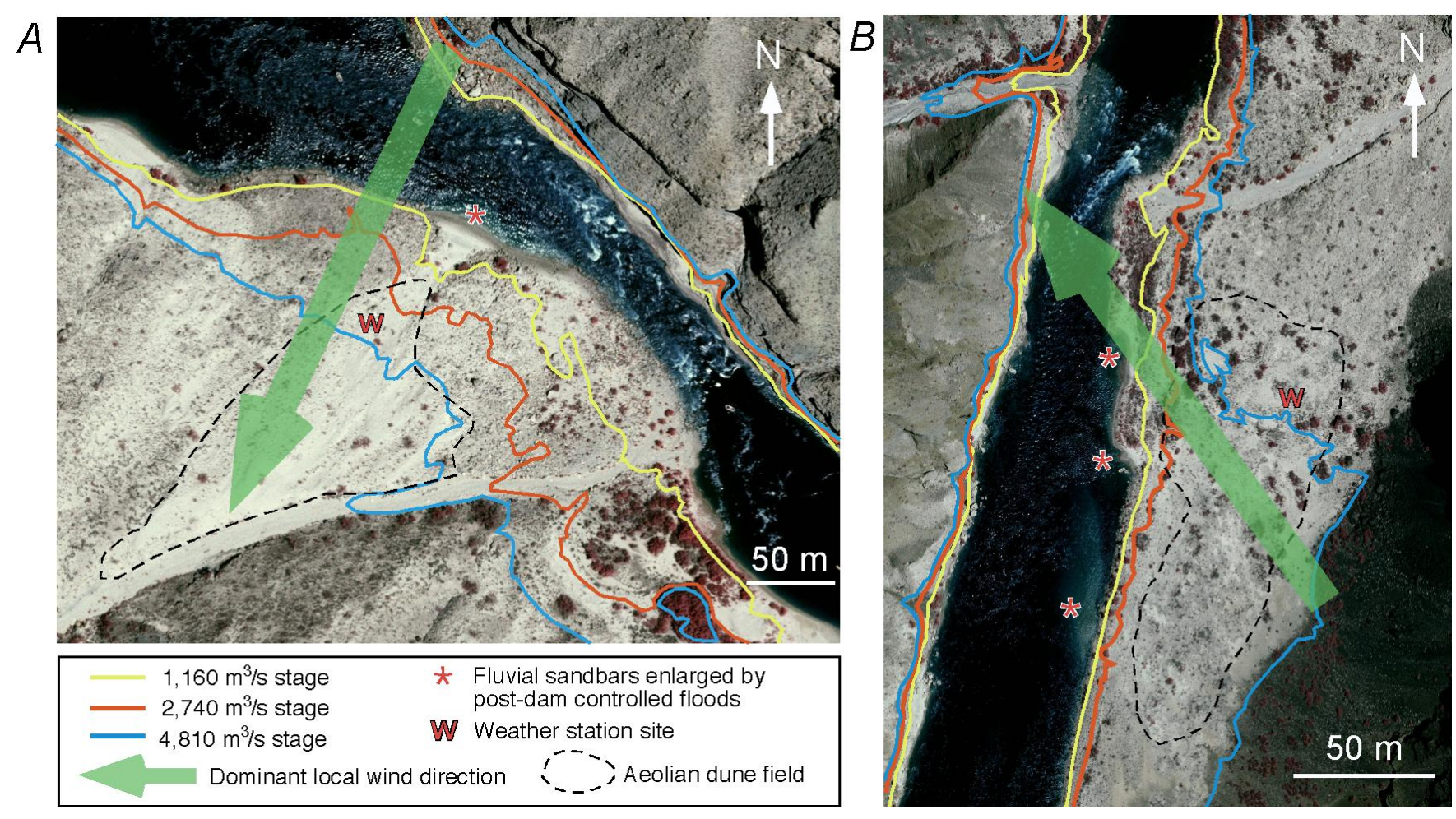

Figure 2. Aerial photographs showing relative positions of shorelines, aeolian dune fields, and locally dominant wind directions for examples of $A$, modern-fluvial-sourced (MFS) and $B$, relict-fluvial-sourced (RFS) aeolian landscapes in the Colorado River corridor, Grand Canyon, Arizona. Both photographs were taken in 2004 at a 
discharge of $227 \mathrm{~m} / \mathrm{s}$. Colored shorelines show the flood stage reached by postdam controlled floods $(1,160$ $\mathrm{m}^{3} / \mathrm{s}$ ), the largest postdam flood (a 2,740 $\mathrm{m}^{3} / \mathrm{s}$ release in 1983), and the largest twentieth-century flood $(4,810$ $\mathrm{m}^{3} / \mathrm{s}$ in 1921; Magirl and others, 2008). In A, MFS aeolian dunes at river mile 123.0 occur on the surface of a broad debris fan. The local prevailing wind direction is from the north-northeast, so the wind can carry sand toward the aeolian dunes from fluvial sandbars left by large, predam floods, smaller postdam controlled floods, and from any low-elevation fluvial sand exposed during low flows because the river, at any discharge, is always upwind of this dune field. In $B$, at river mile 65.5 , the locally dominant wind direction is from the southeast. The dune field there does not receive substantial windblown sand from fluvial sandbars at or below the 1,160 $\mathrm{m}^{3} / \mathrm{s}$ controlled-flood stage, nor would it have during low flows. Only during large, predam floods would the river have supplied new sand to this dune field.

MFS aeolian landscapes receive new windblown sand in the modern, postdam era from adjacent, upwind post-dam fluvial sandbars that form or enlarge during $1,160 \mathrm{~m}^{3} / \mathrm{s}$ controlled floods (fig. $2 A$ ). RFS dune fields, having no modern sandbar adjacent and upwind (fig. $2 B$ ), do not receive any substantial windblown sand supply postdam. Instead, RFS dune sand was derived primarily from deposits of predam floods that were larger than any postdam flows have been (Hereford, 1996; Hereford and others, 1998, 2000; Draut and others, 2008). Even the 2,740 m³ flood of 1983, anomalously high for the postdam era, was not high enough to bring substantial new sand to areas upwind of most RFS dune fields (Magirl and others, 2008). Relict aeolian landscapes include dune fields that formed atop and downwind of alluvial deposits left by predam floods greater than $4,800 \mathrm{~m}^{3} / \mathrm{s}$ (fig. $2 B$ ). Among other applications (such as monitoring invasive species abundance), the vegetation and substrate data presented here demonstrate some ecological differences between MFS aeolian landscapes that receive modern sand supply after controlled floods and RFS aeolian landscapes that do not.

\section{Methods}

This study quantified ground-cover characteristics at 27 sites in aeolian dune fields of the Colorado River corridor in Grand Canyon (fig. 1). The study sites are referred to here in terms of river mile, measured as the distance downstream of Lees Ferry, using the measurement system developed by the U.S. Geological Survey Grand Canyon Monitoring and Research Center (http://www.gcmrc.gov, last accessed May 30, 2011). Of the 27 sites, 15 were in MFS dune fields and 12 were in RFS dune fields. At 14 of those study sites (7 MFS and 7 RFS), wind, rainfall, and sand transport were measured at weather stations; weather-station data has been discussed previously in other reports (Draut and Rubin, 2005, 2006, 2008; Draut and others, 2009a,b, 2010). Those 14 sites were chosen to inform specific river-corridor management objectives and were not a random sample of aeolian landscapes in the river corridor. The full suite of 27 sites represents the range of conditions in Grand Canyon dune fields more completely than did the subset of 14 sites where sand transport and weather were measured. Sites were classified as MFS or RFS on the basis of their position relative to modern sandbars formed or enlarged by controlled floods, flood stages of the predam river (Magirl and others, 2008), and the local wind direction (table 1). Sandbar growth from the 2004 and 2008 controlled floods was assessed by direct field observation and, locally, by topographic surveys (Draut and Rubin, 2006, 2008; Draut and others, 2009a,b, 2010). Several study sites are affected by visitor activity (table 1), which includes campsites and trails. Although areas affected by camping activity cannot be considered to have entirely natural conditions, they were included in this study to represent the range of ground cover in Grand Canyon's aeolian landscapes as thoroughly as possible. 


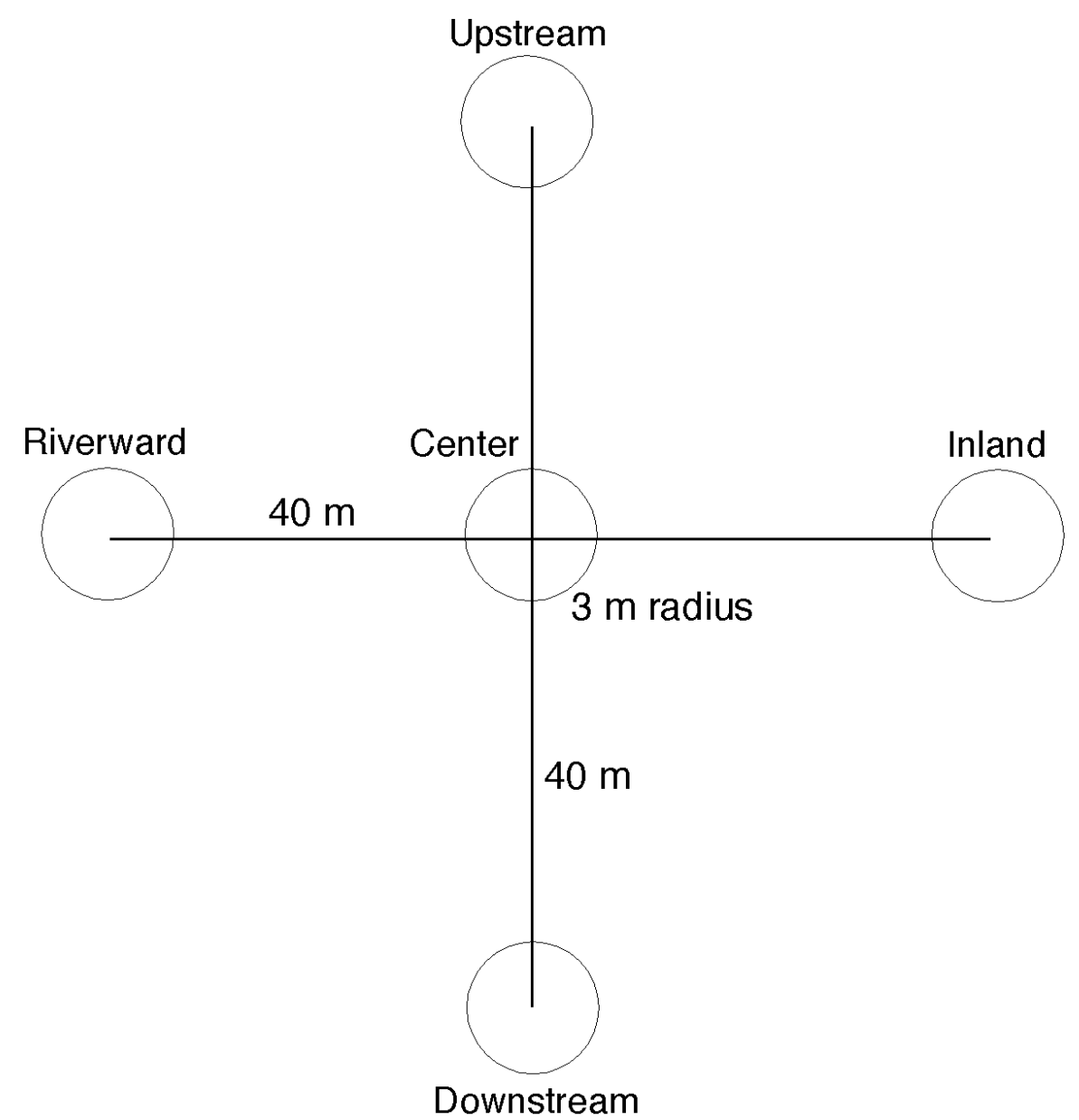

Figure 3. Scale diagram of "pod" configuration used to measure vegetation and substrate, Grand Canyon, Arizona. Two transects of length $40 \mathrm{~m}$ and five circles of radius $3 \mathrm{~m}$ were used (see also Draut and Gillette, 2010).

Vegetation and substrate were measured once at each site, during the summers of 2009 and 2010, by establishing a layout of circles and linear transects referred to here as a pod" (Draut and Gillette, 2010). As shown in figure 3, each pod consisted of two orthogonal transects marked out with a tape reel (one oriented upstream-to-downstream and the other oriented inland-to-riverward) and five 3$\mathrm{m}$-radius circles outlined in the sand (one in the center of the pod and one at the end of each of the four transects). At study sites where weather stations were present, the center of the pod coincided with the position of the sand traps, and the pod's center circle was offset $5 \mathrm{~m}$ in the upstream direction to avoid interfering with the sand traps.

Along each of the transects within a pod, the gap lengths were measured where the measuring tape crossed bare, open sand without rocks, biologic crust, leaf litter, or overhanging plant canopy. Biologic soil crust, a common component of desert ecosystems, consists of cyanobacteria living symbiotically with lichen, mosses, fungi, and algae (Belnap and Lange, 2003). The method of measuring gap length was modified from Herrick and others (2005), using their criteria to define plant canopy gaps, as a means to measure the spacing and abundance of roughness elements, vegetation, and patches of biologic crust that affect aeolian sediment mobility (Ash and Wasson, 1983; Leys and 
Eldridge, 1998; Belnap and Lange, 2003; Goossens, 2004). The proportion of bare, open sand in the dune field then can be estimated by adding all of the measured gap lengths from each transect to compile a cumulative gap length measurement and representing that total gap length as a percentage of the total transect length.

Within each of the five circles in a pod, the percentage of vegetation cover was measured, as were the types of substrate in which the plants were growing. Vegetation was identified to species level wherever possible, using names and descriptions given by Taylor (1992), Williams (2000), and Huisinga and others (2006) and maintaining consistency with the U.S. Department of Agriculture plant database (http://plants.usda.gov/, last accessed September 26, 2011). Substrates were divided into four categories: open sand, biologic soil crust, leaf litter, and rock. To estimate the percentage of cover of both plants and substrate, a disc of known size was compared with the area covered by a plant, rock, patch of soil crust, or other object of interest. The disc (radius $20 \mathrm{~cm}$ ) has an area $\left(0.13 \mathrm{~m}^{2}\right)$ approximately half of one percent of the circle size studied $\left(28.3 \mathrm{~m}^{2}\right)$. By holding a disc of known radius above plants or patches of biologic crust to gage their size and percent coverage, the study teams avoided disturbing the ground surface unnecessarily as would happen from handling plants or placing measuring devices directly on sensitive, soil-encrusted ground. At the 14 weather-station sites, the maximum height of each type of plant within the circles also was recorded. Efforts were made to record qualitative observations of any additional plant species that were near but not within the circles. Field sites were photographed, transect orientations were measured with a compass, and recent dominant wind directions were estimated by using compass measurements of dune slipface and sand-shadow orientations (table 1).

\section{Results and Discussion}

Table 1 and figures 4-6 summarize the vegetation and substrate properties measured. Tables 228 provide detailed information for each study site. In cases where species identification was uncertain, plants were identified by their family or genus, or by designation as annual or perennial grass, forb, or shrub. Vegetation assemblages at the study sites typically contained between 10 and 20 different plant species (table 1). Native plants common to aeolian dune fields in Grand Canyon included perennial bunchgrasses such as Indian rice grass (Achnatherum hymenoides, also known as genus Oryzopsis), and several species of dropseed (Sporobolus spp.). Common native shrubs and forbs included wire lettuce (Stephanomeria pauciflora), seepweed (Suaeda moquinii), saltbush (Atriplex spp.), dicoria (Dicoria canescens), sand verbena (Abronia elliptica), globemallow (Sphaeralcea sp.), and several members of the Asteraceae family. Prickly-pear (Opuntia spp.) and beavertail (Opuntia basilaris) cactus also were common, some of which were planted intentionally by the National Park Service to slow erosion (for example, at the upper site at mile $24.7 \mathrm{~L}$ ). Common large shrubs and trees included mesquite (Prosopis glandulosa), catclaw acacia (Acacia greggii), and downstream of river mile 200, creosote (Larrea tridentata). Nonnative plants included brome grasses (Bromus spp.) such as cheatgrass, red brome, and ripgut brome, Russian thistle (Salsola tragus), and at study sites nearest the Colorado River, tamarisk trees (Tamarix ramosissima).

Ground cover on MFS aeolian landscapes was found to be different from that on RFS aeolian landscapes, with open, bare sand more abundant in MFS dune fields (fig. 4). Figure 5A shows vegetation abundance in the two groups of dune fields. The two groups had similar median values (15.5 percent vegetation cover on MFS dunes, compared with 18.9 percent on RFS dunes), but higher maximum values occurred at RFS sites. A Welch's $t$ test comparing mean vegetation cover on MFS and RFS sites yields $p=0.07$, just above the threshold of generally accepted significant difference $(0.05)$. 
MFS sites, however, have significantly less biologic soil crust than do RFS dune fields. The median value for biologic crust as a proportion of the substrate is more than 20 times greater for RFS landscapes than for MFS landscapes (27 percent compared to 1.2 percent; fig. $5 B$ ), and the means of the two populations are significantly different $(p<0.005)$. The cumulative gap length measured along transects in MFS dune fields is significantly greater than that measured in RFS dune fields (fig. $5 C$ ), with $p<0.000005$. As shown in figures 5 and 6 , the difference in gap length between MFS and RFS sites is primarily attributable to the greater abundance of biologic soil crust at RFS study sites.
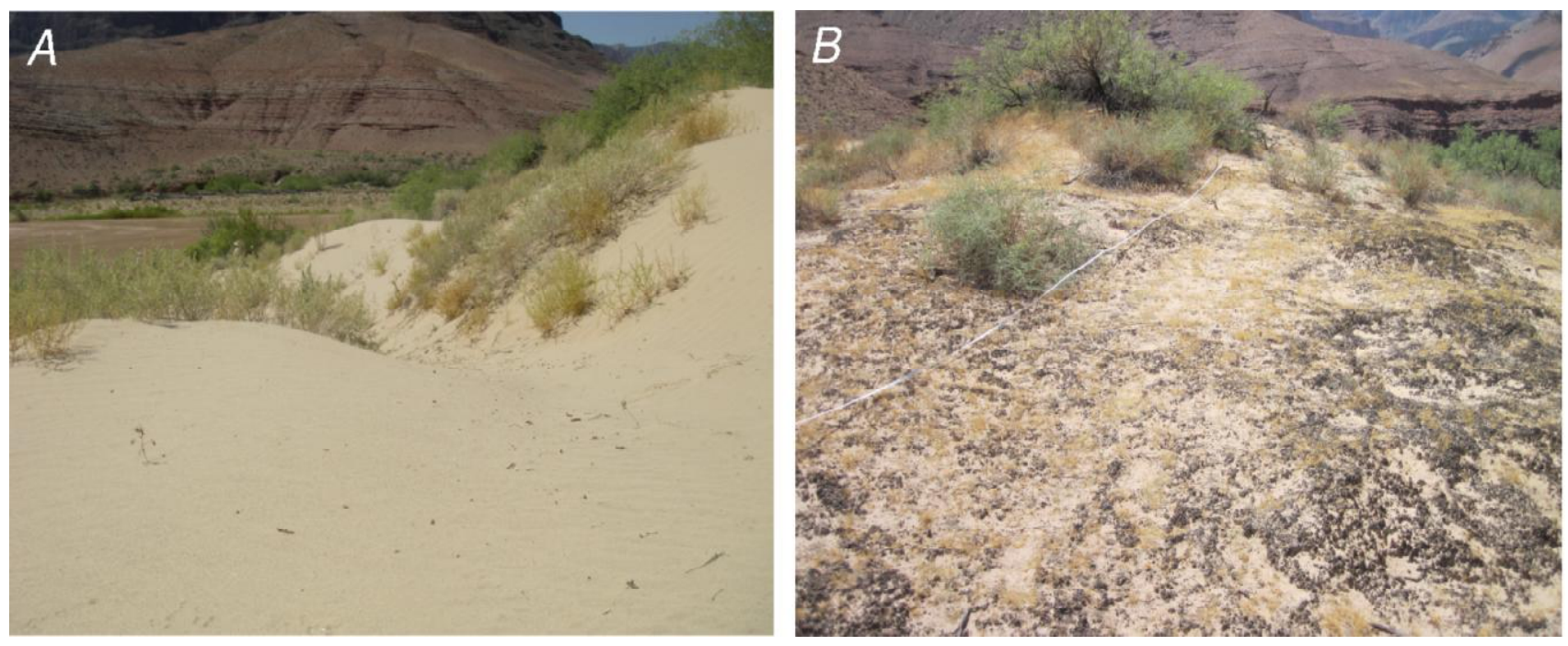

Figure 4. Field photographs from Grand Canyon, Arizona, showing ground cover on $A$, an MFS dune field at river mile 69.5, and $B$, an RFS dune field at river mile 68.1. Dark-colored biologic soil crust appears in the foreground of $B$, and a white measuring tape is visible on the ground.

The vegetation assemblages measured on aeolian dune fields in the Colorado River corridor can inform future monitoring efforts regarding the spread of nonnative plants in Grand Canyon National Park. In particular, Russian thistle (Salsola tragus) and brome grasses (Bromus spp.) are especially adept at colonizing disturbed, sandy ground surfaces such as occur in aeolian dunes (D'Antonio and Vitousek, 1992; Belnap and others, 2009), and are common throughout Grand Canyon. Each of these is able to spread rapidly and is considered an invasive plant in southwest desert ecosystems. At one study site, river mile 70.0 L (lower site), the abundance of Russian thistle increased substantially after 2007 (fig. 7). At the time of the vegetation survey there in July 2009, Russian thistle covered more than 18 percent of the ground surface and accounted for 53 percent of the total vegetation present, composing the highest Russian thistle abundance of any site studied (table 15, fig. 7). There was no significant difference between the abundance in MFS and RFS dune fields of either Russian thistle or brome (figs. 8,9 ), with $t$ tests yielding $\mathrm{p}=0.22$ for the Russian thistle comparison and $\mathrm{p}=0.39$ for brome. The lack of significant differences in abundance of those two plants between MFS and RFS sites suggests that the supply of new windblown material (including sediment and plant seeds) from controlled-flood deposits upwind of the MFS sites does not contribute significantly to the ability of those plants to colonize and spread in Grand Canyon. It is likely that other factors, such as spring rainfall, are more important to Russian thistle and brome abundance than is windborne seed supply from flood deposits. In general, 

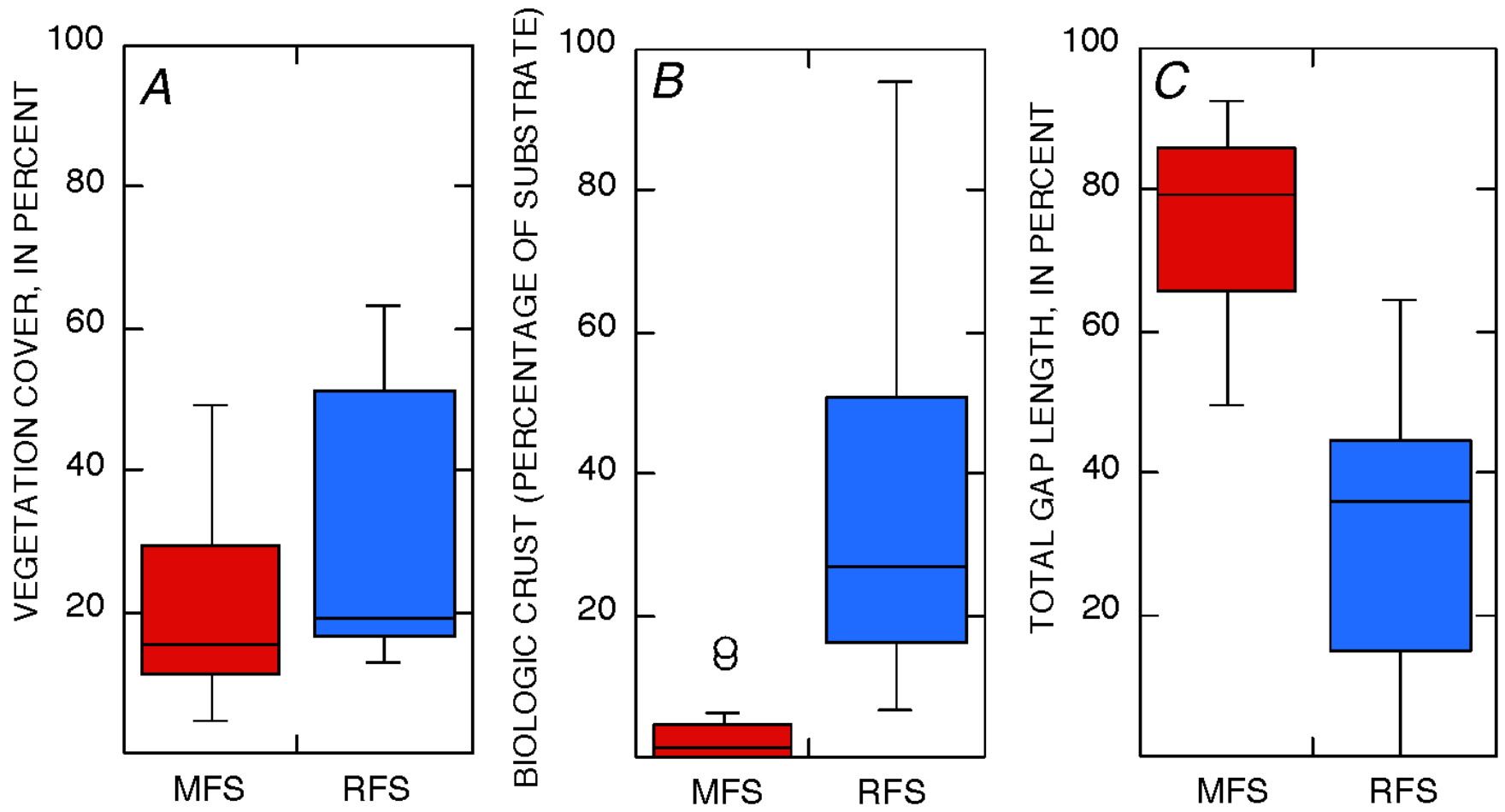

TFigure 5. Vegetation and substrate measured at 27 sites in aeolian landscapes of the Colorado River corridor in Grand Canyon, Arizona. Sites are grouped as modern-fluvial-sourced (MFS, red boxes) and relict-fluvialsourced (RFS, blue boxes) dune fields. Boxes span the interquartile range of data; horizontal line through each box is the median value. Circles show outlier points with values greater than 1.5 times the interquartile range, and whiskers show the highest and lowest non-outlier points. A, Vegetation abundance measured in circular plots. B, Biologic crust abundance measured in circular plots. C, Proportion of the total length of linear transects comprising gaps where only open, bare sand was present, without biologic crust, leaf litter, rocks, or overhanging plant canopy.

plant species richness was similar at MFS and RFS study sites (table 1), with $p=0.15$, indicating no significant difference in the number of species occurring at sites of each type.

Russian thistle and brome grasses may be somewhat less abundant on aeolian landscapes of the Colorado River corridor in Grand Canyon than they are on aeolian landscapes of the Colorado River corridor through Cataract Canyon, Utah, $350 \mathrm{~km}$ upstream of Glen Canyon Dam in Canyonlands National Park. Differences in vegetation composition within the river corridor in Grand and Cataract Canyons could arise in part because of their different land-use histories - historically, rangeland surrounding, and even within, Cataract Canyon was used more intensively for livestock foraging than were the rims of Grand Canyon (Webb and others, 2004); exploring detailed connections between livestock use and vegetation assemblage is beyond the scope of this report. Measuring vegetation at 13 sites within MFS aeolian dune fields in Cataract Canyon, Draut and Gillette (2010) found that Russian thistle was present at 85 percent of study sites (11 of 13) and, on average, covered 1.8 percent of the ground area and composed 5.8 percent of the total vegetation (fig. 10). In Grand Canyon, in contrast, Russian thistle was present at only 40 percent of MFS study sites (6 of 15) and, on average, covered 0.4 percent of the ground area and composed 1.7 percent of the total vegetation. Invasive brome grasses 

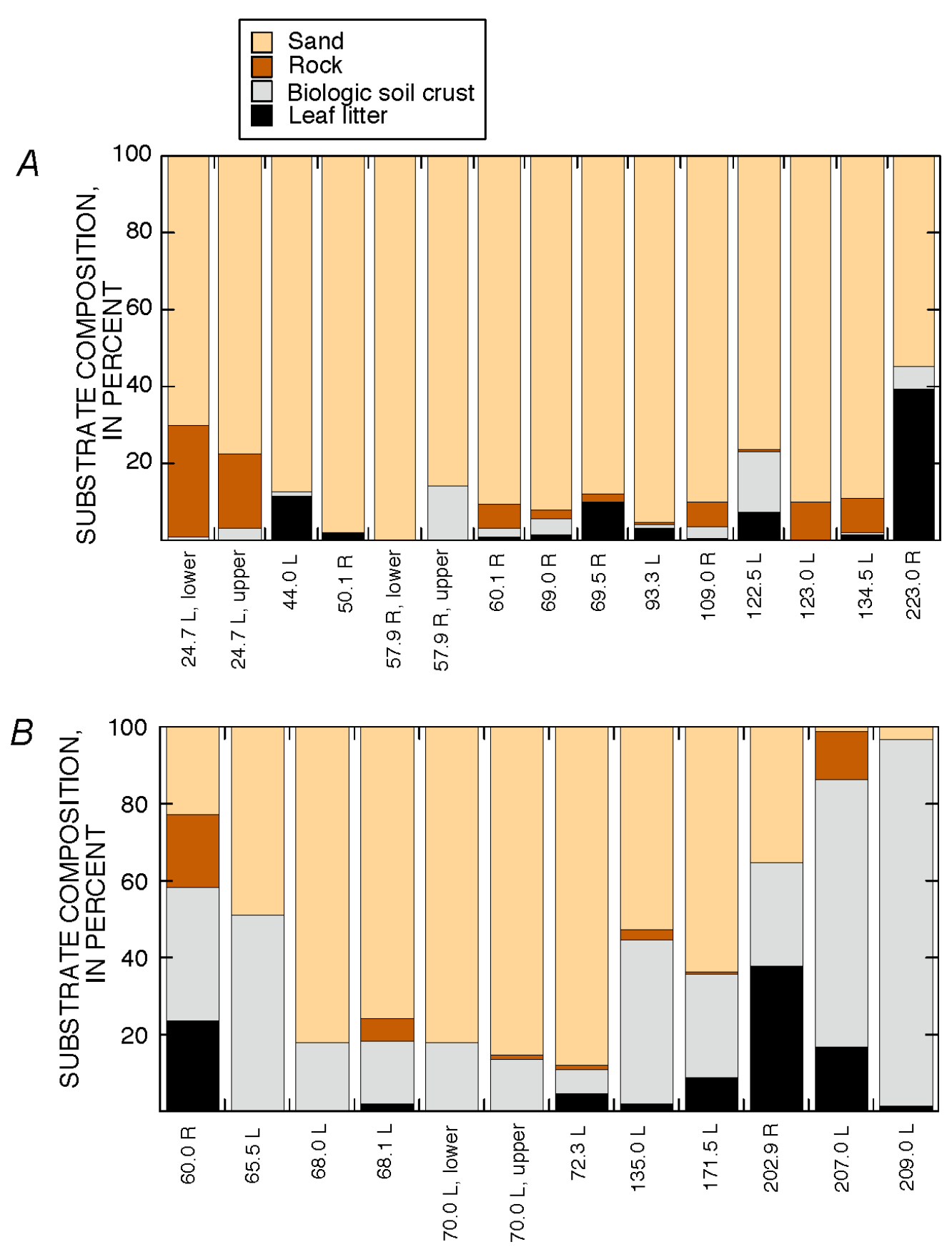

Figure 6. Substrate composition at each study site in Grand Canyon, Arizona, showing proportions of sand, rock, biologic soil crust, and leaf litter. $A$, sites in modern-fluvial-sourced (MFS) aeolian dune fields; $B$, sites in relictfluvial-sourced (RFS) dune fields.

were present at 100 percent of MFS study sites in Cataract Canyon, covering 2.8 percent of the ground area and composing 11.2 percent of the vegetation (Draut and Gillette, 2010). In Grand Canyon, brome was found at 80 percent of the MFS study sites, occupying 2.4 percent of the ground area and composing 8.9 percent of the total vegetation. Overall vegetation cover was similar in dune fields of Cataract and Grand Canyons ( $>00.05$; fig. $9 A$ ). Although the differences between mean values of Russian thistle and brome abundance in Grand Canyon and Cataract Canyon are not great enough to 

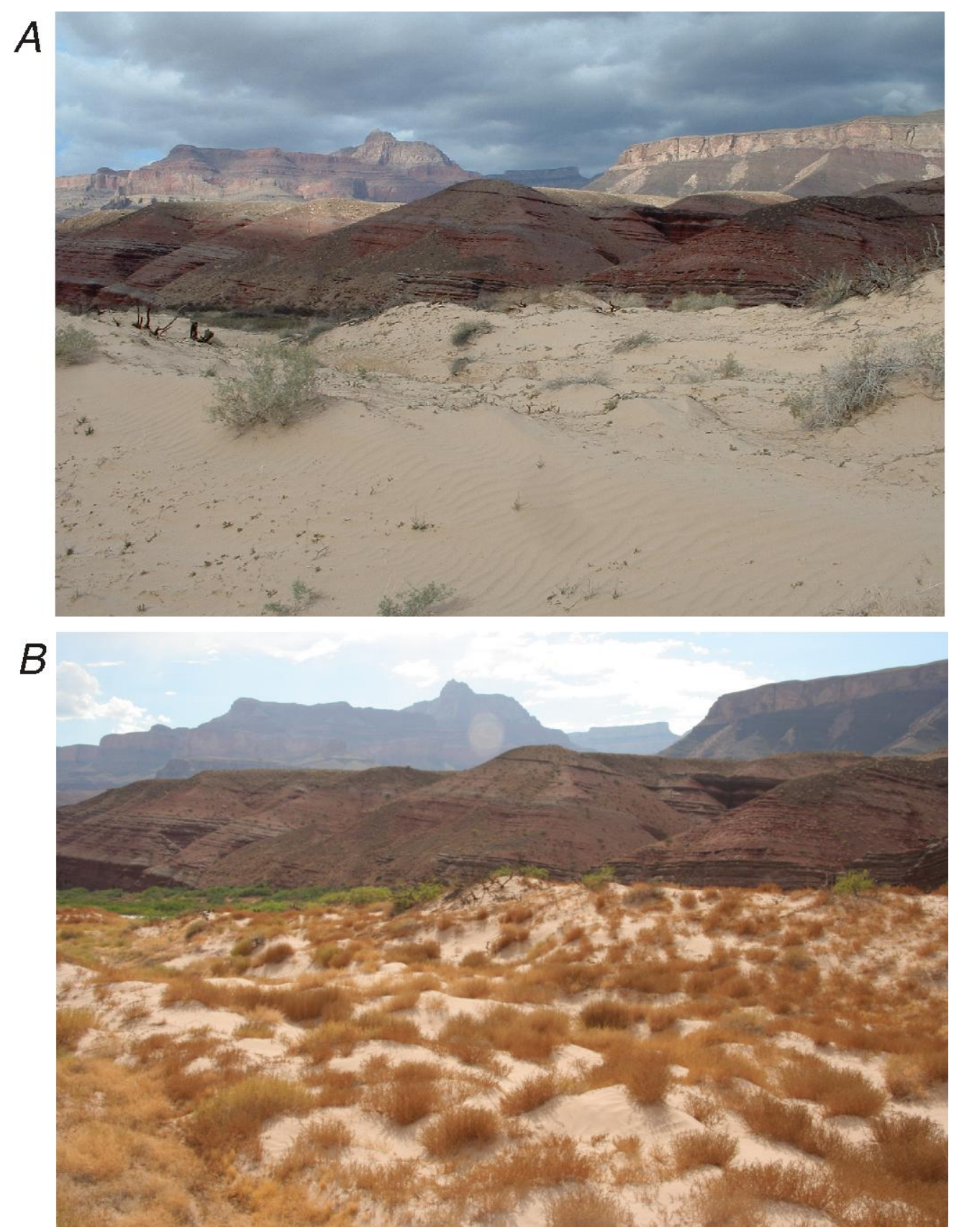

[0Figure 7. Russian thistle (Salsola tragus) spreading rapidly across an aeolian landscape in Grand Canyon, Arizona, at river mile 70 (lower site). A, Photograph taken in February 2007 shows aeolian dunes sparsely vegetated with native seepweed (Suaeda sp.) and mesquite (Prosopis glandulosa). B, The same site photographed in July 2010 had much denser vegetation cover, populated almost exclusively by invasive Russian thistle.

pass a $t$ test for statistical significance $(\mathrm{p}=0.13$ for Russian thistle coverage and $\mathrm{p}=0.34$ for brome coverage), the results might indicate incipient or developing trends that would be worthwhile to monitor in the future regarding Grand Canyon in relation to other reaches of the Colorado River corridor and its tributaries. 

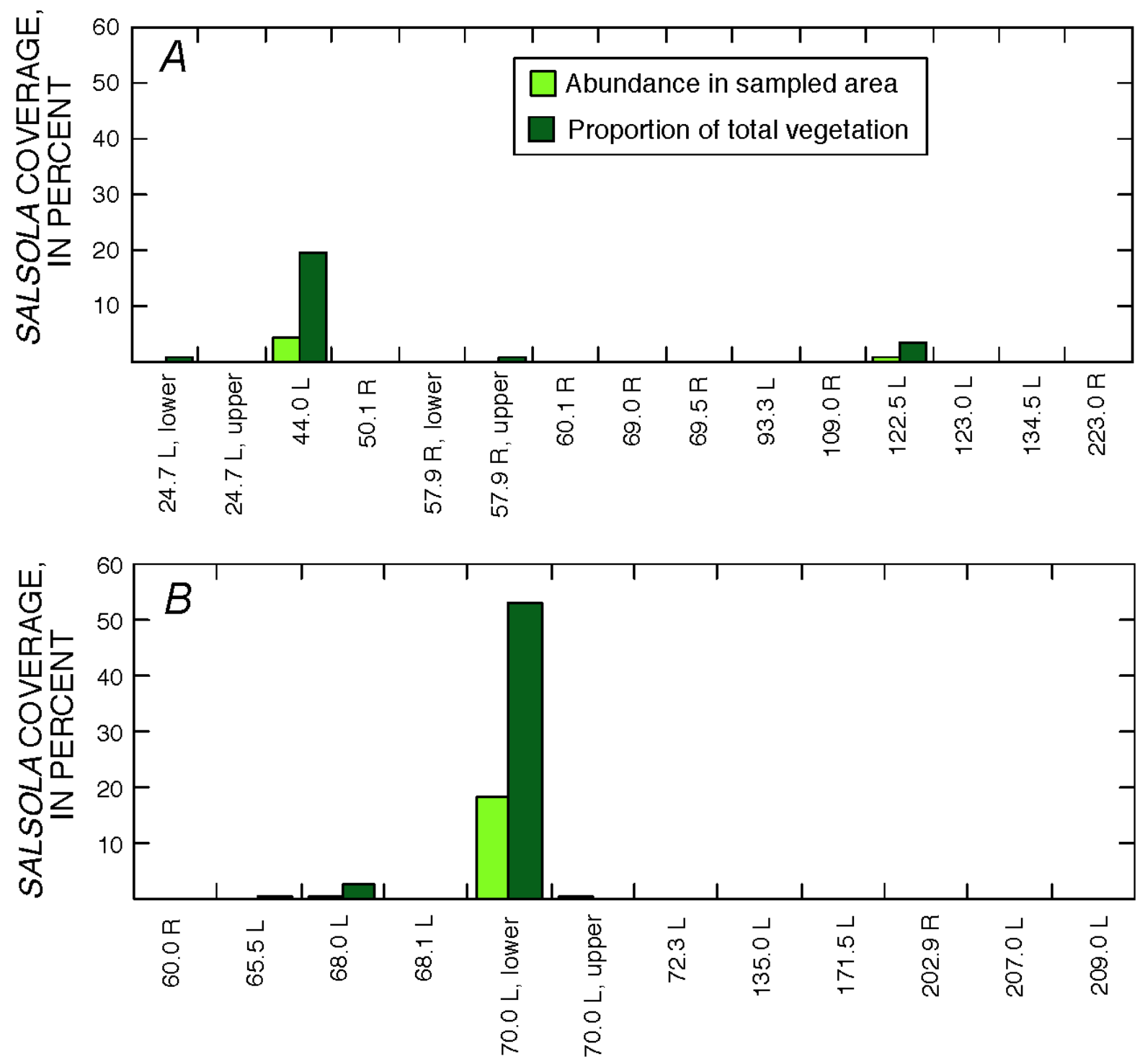

DFigure 8. Abundance of invasive Russian thistle (Salsola tragus) on A, MFS dune fields and B, RFS dune fields, Grand Canyon, Arizona.

Visitor impacts are evident at seven of the study sites (table 1). The five MFS sites with visitor use are all camps used by river runners and, at river mile $44.0 \mathrm{~L}$, occasionally used by backpackers. The two RFS sites with evidence of visitor use, at river mile $68.1 \mathrm{~L}$ and river mile $171.5 \mathrm{~L}$, each contain one trail approximately $1 \mathrm{~m}$ wide. Among MFS sites, significant differences are not apparent between the five sites used as camps and the 10 noncamps. Comparing vegetation coverage at the MFS camps to the MFS noncamps yields $p=0.05$ (borderline significant), whereas comparing biologic crust abundance and total gap length yields $p=0.2$ and $p=0.07$, respectively. Although river runners commonly choose campsites that contain open, bare sand, and their camping activities probably contribute to maintaining open sand area, it is possible that the lack of strongly significant differences between camp and noncamp ground cover in MFS dune fields reflects river runners' preference for camping in areas closer to the river, on fluvial sandbars that are below the elevations of the study sites discussed here. If that is 

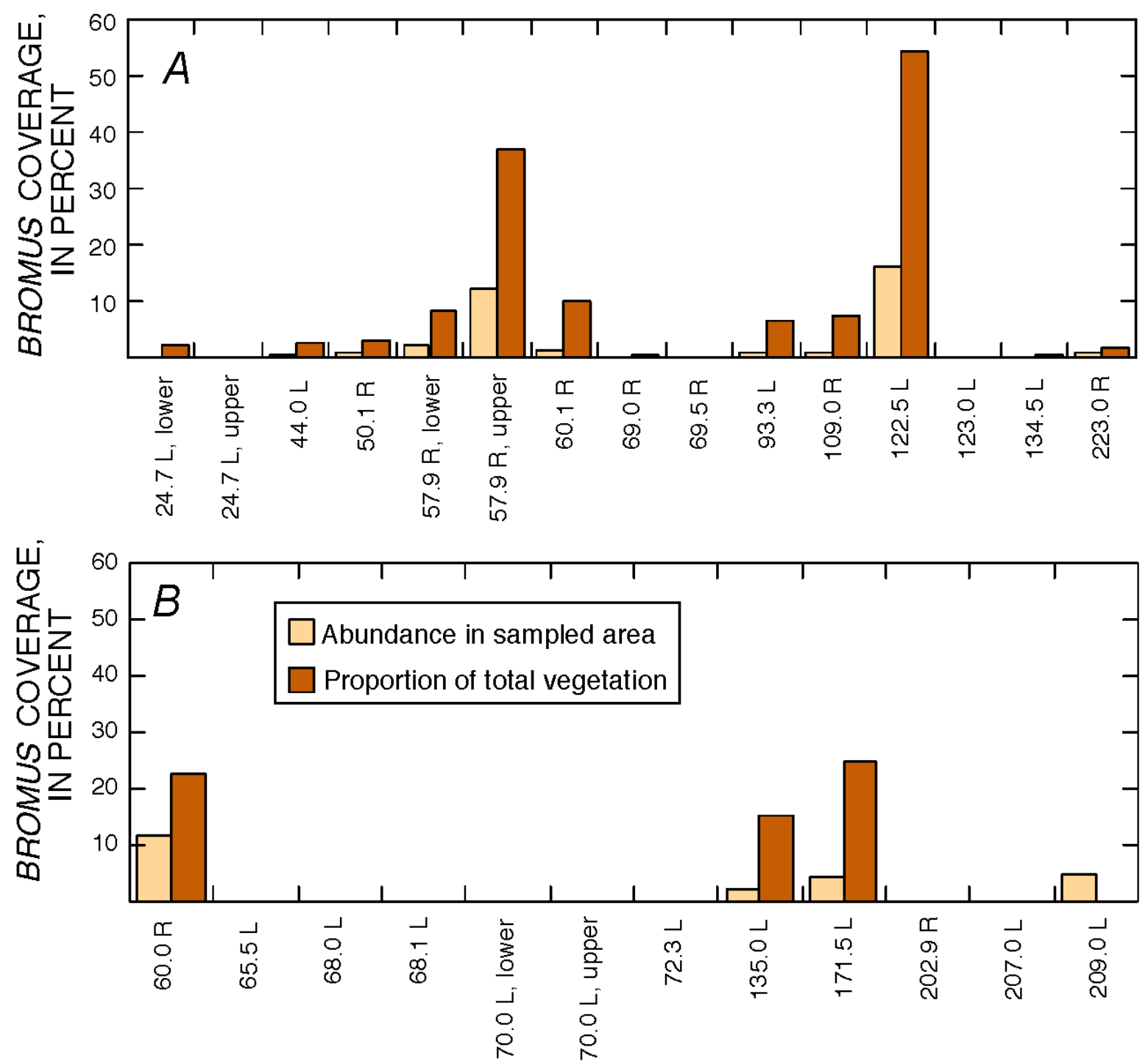

Figure 9. Abundance of invasive brome grasses (Bromus spp.) on A, MFS dune fields and $B$, RFS dune fields, Grand Canyon, Arizona.

the case, then the higher-elevation, aeolian-dune portions of camps probably receive less visitor use than do the lower-elevation fluvial sandbars.

The differences in ground cover between MFS and RFS dune fields in Grand Canyon (figs. 4, 5) point to changes in the ecosystem that apparently developed with the lack of modern sand supply to RFS dune fields. Those dune fields that can receive modern sand supply from controlled-flood sandbars (fluvial deposits at or below the $1,160 \mathrm{~m}^{3} / \mathrm{s}$ stage of the Colorado River) have more open, bare sand space than occurs on dune fields without modern sand supply, and MFS landscapes contain significantly less biologic soil crust than do RFS landscapes. That less biologic crust was found on MFS dunes is consistent with biologic crust organisms having difficulty surviving and growing in environments where they are abraded or buried by much active windblown sand transport (J. Belnap, personal communication, 2006). Evidently, lack of sand supply to RFS landscapes in the absence of very large, 

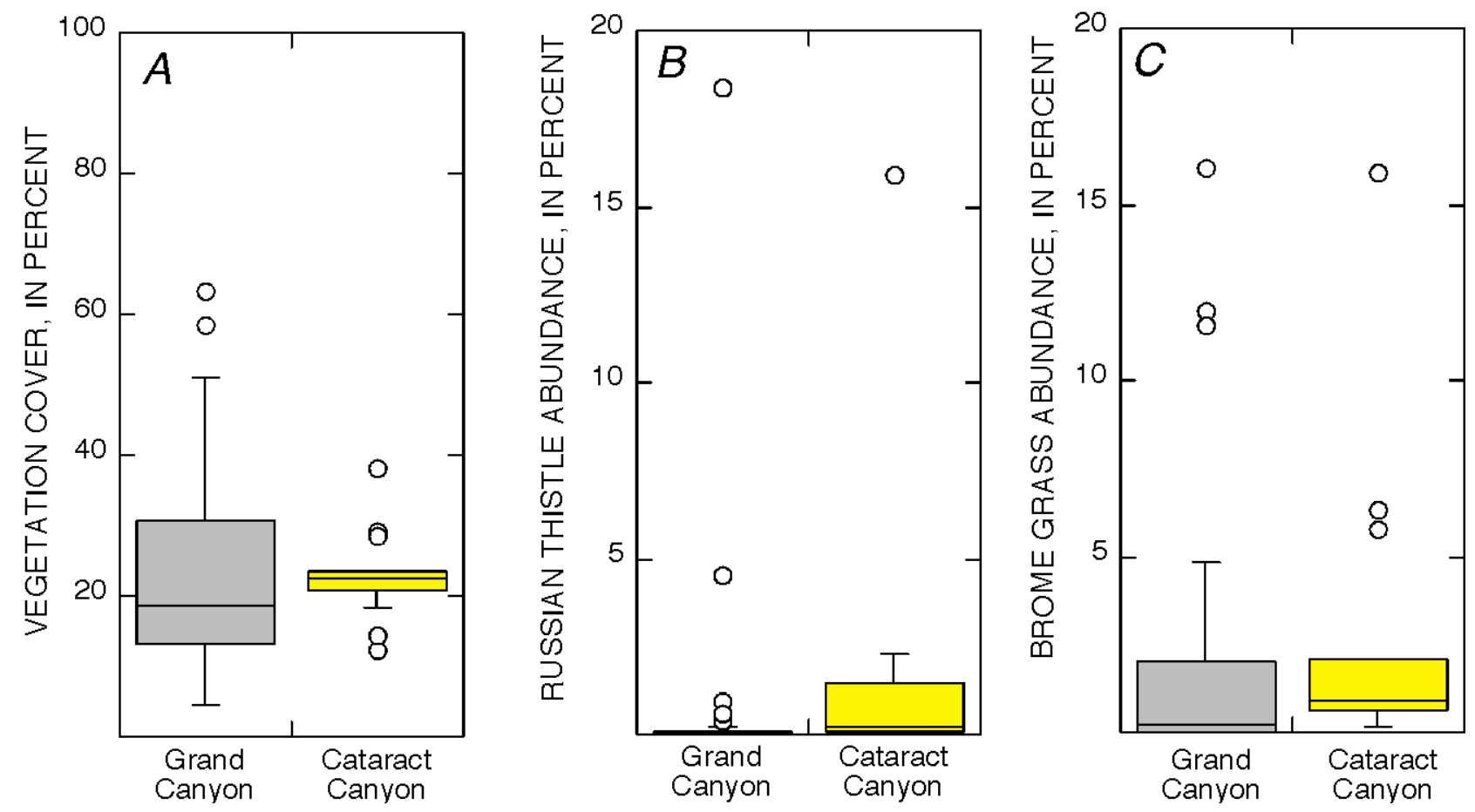

Figure 10. Comparison of A, total vegetation cover, B, invasive Russian thistle (Salsola tragus) abundance, and C, invasive brome grass (Bromus spp.) abundance in aeolian dune fields of Grand Canyon, Arizona (gray boxes, 27 study sites), and Cataract Canyon, Utah (yellow boxes, 13 study sites). Cataract Canyon data are from Draut and Gillette (2010). Boxes span the interquartile range of data; horizontal line through each box is the median value. Circles show outlier points with values greater than 1.5 times the interquartile range, and whiskers show the highest and lowest non-outlier points. In $\mathrm{B}$ and $\mathrm{C}$, abundance is expressed in terms of the percentage of the ground covered by those species.

sediment-rich floods facilitates growth of biologic crust and, to a lesser degree, possibly vegetation, leading over time to less bare sand ground cover on aeolian dunes.

\section{Conclusions}

Characterizing vegetation and substrate on aeolian dune fields provides a basis from which to assess future ecological changes in the Colorado River corridor through Grand Canyon National Park. Aeolian landscapes that are downwind of where modern controlled flooding deposits new sandbars (modern-fluvial-sourced dune fields) have more open, bare sand and less biologic soil crust, and in some cases less vegetation, than those that have received little or no new windblown sand since river regulation began in the 1960s (relict-fluvial-sourced dune fields). The plant community composition includes invasive species, such as Russian thistle and brome grasses, that thrive in loose, disturbed substrate, such as the sand that composes aeolian dunes. Those species may be somewhat less abundant in Grand Canyon than they are upstream of Lake Powell in Cataract Canyon, but nonetheless require the attention of land managers. These findings can be used with similar investigations in other geomorphic settings in Grand Canyon and elsewhere in the Colorado River corridor to evaluate the health of the Colorado River ecosystem over time. 


\section{Acknowledgments}

This study was supported by the U.S. Bureau of Reclamation through the U.S. Geological Survey Grand Canyon Monitoring and Research Center, under National Park Service study GRCA00208. Helen Fairley, Dave Rubin, and Ted Melis are thanked for valuable discussions. Sarah Baden, Carol Fritzinger, Clay Nelson, Lynn Roeder, Greg Woodall, and more than 30 youth volunteers collected vegetation and substrate data that went into this report. Many thanks to Grand Canyon Youth, Flagstaff, Arizona, for providing field support throughout this study. Lori Makarick, Melissa McMaster, and Barbara Ralston provided helpful review comments that improved the manuscript.

\section{References Cited}

Ash, J.E., and Wasson, R.J., 1983, Vegetation and sand mobility in the Australian desert dunefield: Zeitschrift für Geomorphologie, supp. v. 45, p. 7-25.

Belnap, J., and Lange, O.L., eds., 2003, Biological soil crusts-Structure, function, and management (Ecological Studies series, v. 150): Berlin, Springer-Verlag.

Belnap, J., Reynolds, R.L., Reheis, M.C., Phillips, S.L., Urban, F.E., and Goldstein, H.L., 2009, Sediment losses and gains across a gradient of livestock grazing and plant invasion in a cool, semiarid grassland, Colorado Plateau, USA: Aeolian Research, v. 1, p. 27-43.

Beus, S.S., Carothers, S.W., and Avery, C.C., 1985, Topographic changes in fluvial terrace deposits used as campsite beaches along the Colorado River in Grand Canyon: Arizona-Nevada Academy of Science Journal, v. 20, p. 111-120.

D'Antonio, C.M., and Vitousek, P.M., 1992, Biological invasions by exotic grasses, the grass/fire cycle, and global change: Annual Review of Ecology and Systematics, v. 23, p. 63-87.

Draut, A.E., and Rubin, D.M., 2005, Measurements of wind, aeolian sand transport, and precipitation in the Colorado River corridor, Grand Canyon, Arizona-November 2003 to December 2004: U.S. Geological Survey Open-File Report 2005-1309. (http://pubs.usgs.gov/of/2005/1309/)

Draut, A.E., and Rubin, D.M., 2006, Measurements of wind, aeolian sand transport, and precipitation in the Colorado River corridor, Grand Canyon, Arizona-January 2005 to January 2006: U.S. Geological Survey Open-File Report 2006-1188, 88 p. (http://pubs.usgs.gov/of/2006/1188/)

Draut, A.E., Rubin, D.M., Dierker, J.L., Fairley, H.C., Griffiths, R.E., Hazel, J.E., Jr., Hunter, R.E., Kohl, K., Leap, L.M., Nials, F.L., Topping, D.J., and Yeatts, M., 2008, Application of sedimentarystructure interpretation to geoarchaeological studies in the Colorado River corridor, Grand Canyon, Arizona, USA: Geomorphology, v. 101, no. 3, p. 497-509.

Draut, A.E., and Rubin, D.M., 2008, The role of eolian sediment in the preservation of archeologic sites along the Colorado River corridor in Grand Canyon National Park, Arizona: U.S. Geological Survey Professional Paper 1756. (http://pubs.usgs.gov/pp/1756/)

Draut, A.E., Andrews, T., Fairley, H.C., and Brown, C.R., 2009a, 2007 weather and aeolian sandtransport data from the Colorado River corridor, Grand Canyon, Arizona: U.S. Geological Survey Open-File Report 2009-1098, 110 p. (http://pubs.usgs.gov/of/2009/1098/)

Draut, A.E., Sondossi, H.A., Hazel, J.E. Jr., Fairley, H.C., Andrews, T., Brown, C.R., and Vanaman, K.M., 2009b, 2008 weather and aeolian sand-transport data from the Colorado River corridor, Grand Canyon, Arizona: U.S. Geological Survey Open-File Report 2009-1190, 98 p.

(http://pubs.usgs.gov/of/2009/1190/) 
Draut, A.E., Sondossi, H.A., Dealy, T.P., Hazel, J.E. Jr., Fairley, H.C., and Brown, C.R., 2010a, 2009 weather and aeolian sand-transport data from the Colorado River corridor, Grand Canyon, Arizona: U.S. Geological Survey Open-File Report 2010-1166, 98 p. (http://pubs.usgs.gov/of/2010/1166/)

Draut, A.E., Hazel, J.E. Jr., Fairley, H.C., and Brown, C.R., 2010b, Aeolian reworking of sandbars from the March 2008 Glen Canyon Dam high flow experiment in Grand Canyon, in Melis, T.S., Hamill, J.F., Coggins, L.G., Jr., Grams, P.E., Kennedy, T.A., Kubly, D.M., and Ralston, B.E., eds., Proceedings of the Colorado River Basin Science and Resource Management Symposium, November 18-20, 2008, Scottsdale, Arizona: U.S. Geological Survey Scientific Investigations Report 20105135, p. 325-331.

Draut, A.E., and Gillette, E.R., 2010, Vegetation and substrate on aeolian landscapes in the Colorado River corridor, Cataract Canyon, Utah: U.S. Geological Survey Open-File Report 2010-1273, 61 p. (http://pubs.usgs.gov/of/2010/1273/)

Gloss, S.P., Lovich, J.E., and Melis, T.S., eds., 2005, The state of the Colorado River ecosystem in Grand Canyon: U.S. Geological Survey Circular 1282.

Goossens, D., 2004, Effect of soil crusting on the emission and transport of wind-eroded sedimentField measurements on loamy sandy soil: Geomorphology, v. 58, p. 145-160.

Hazel, J.E.., Jr., Grams, P.E., Schmidt, J.C., and Kaplinski, M., 2010, Sandbar response in Marble and Grand Canyons, Arizona, following the 2008 high-flow experiment on the Colorado River: U.S. Geological Survey Scientific Investigations Report 2010-5015, 52 p.

Hereford, R., 1996, Surficial geology and geomorphology of the Palisades Creek area, Grand Canyon National Park, Arizona: U.S. Geological Survey Miscellaneous Investigations Series Map I-2449, scale $1: 2,000$.

Hereford, R., Burke, K.J., and Thompson, K.S., 1998, Quaternary geology and geomorphology of the Nankoweap Rapids area, Marble Canyon, Arizona: U.S. Geological Survey Geologic Investigations Series Map I-2608, scale 1:4,600.

Hereford, R., Burke, K.J., and Thompson, K.S., 2000, Quaternary geology and geomorphology of the Granite Park area, Grand Canyon, Arizona: U.S. Geological Survey Geologic Investigations Series Map I-2662, scale 1:2,000.

Herrick, J.E., Van Zee, J.W., Havstad, K.M., Burkett, L.M., and Whitford, W.G., 2005, Monitoring manual for grassland, shrubland, and savanna ecosystems: Las Cruces, New Mexico, U.S. Department of Agriculture, distributed by University of Arizona Press, $36 \mathrm{p}$.

Huisinga, K., Makarick, L., and Watters, K., 2006, River and desert plants of the Grand Canyon: Missoula, Montana, Mountain Press Publishing Company, $261 \mathrm{p}$.

Kearsley, L.H., Schmidt, J.C., and Warren, K.D., 1994, Effects of Glen Canyon Dam on Colorado River sand deposits used as campsites in Grand Canyon National Park, USA: Regulated Rivers, Research and Management, v. 9, p. 137-149.

Leys, J.F., and Eldridge, D.J., 1998, Influence of cryptogamic crust disturbance to wind erosion on sand and loam rangeland soils: Earth Surface Processes and Landforms, v. 23, p. 963-974.

Magirl, C.S., Breedlove, M.J., Webb, R.H., and Griffiths, P.G., 2008, Modeling water-surface elevations and virtual shorelines for the Colorado River in Grand Canyon, Arizona: U.S. Geological Survey Scientific Investigation Report 2008-5075, 40 p. (http://pubs.usgs.gov/sir/2008/5075/)

Melis, T.S., ed., 2011, Effects of three high-flow experiments on the Colorado River ecosystem downstream from Glen Canyon Dam, Arizona: U.S. Geological Survey Circular 1366, 147 p. 
Rubin, D.M., Topping, D.J., Schmidt, J.C., Hazel, J., Kaplinski, M., and Melis, T.S., 2002, Recent sediment studies refute Glen Canyon Dam hypothesis: Eos (American Geophysical Union Transactions), v. 83, p. 273, 277-278.

Schmidt, J.C., and Graf, J.B., 1990, Aggradation and degradation of alluvial sand deposits, 1965 to 1986, Colorado River, Grand Canyon National Park, Arizona: U.S. Geological Survey Professional Paper 1493, 74 p.

Taylor, R.J., 1992, Sagebrush country; a wildflower sanctuary: Missoula, Montana, Mountain Press Publishing Company, 209 p.

Topping, D.J., Rubin, D.M., and Vierra, L.E., Jr., 2000, Colorado River sediment transport 1-Natural sediment supply limitation and the influence of Glen Canyon Dam: Water Resources Research, v. 36, p. 515-542.

Topping, D.J., Schmidt, J.C., and Vierra, L.E., Jr., 2003, Computation and analysis of the instantaneousdischarge record for the Colorado River at Lees Ferry, Arizona-May 8, 1921, through September 30, 2000: U.S. Geological Survey Professional Paper 1677, 118 p.

Topping, D.J., Rubin, D.M., Grams, P.E., Griffiths, R.E., Sabol, T.A., Voichick, N., Tusso, R.B., Vanaman, K.M., and McDonald, R.R., 2010, Sediment transport during three controlled-flood experiments on the Colorado River downstream from Glen Canyon Dam, with implications for eddysandbar deposition in Grand Canyon National Park: U.S. Geological Survey Open-File Report 2010$1128,111 \mathrm{p}$.

Turner, R.M., and Karpiscak, M.M., 1980, Recent vegetation changes along the Colorado River between Glen Canyon Dam and Lake Mead, Arizona: U.S. Geological Survey Professional Paper $1132,125 \mathrm{p}$.

U.S. Department of Agriculture, 2011, Plants Database, http://plants.usda.gov/

Webb, R.H., Schmidt, J.C., Marzolf, G.R., and Valdez, R.A., eds., 1999, The controlled flood in Grand Canyon: Washington, D.C., American Geophysical Union, Monograph 110, p. 1-21.

Webb, R.H., Belnap, J., and Weisheit, J.S., 2004, Cataract Canyon-A human and environmental history of the rivers in Canyonlands: Salt Lake City, University of Utah Press, 268 p.

Williams, D.B., 2000, A naturalist's guide to canyon country: Guilford, Conn., Globe Pequot Press, 188 p. 